\title{
Orfeu e o gato: Jorge de Lima e Ana Cristina César, uma trajetória de releitura poética \\ Viviana Bosi
}

Uma das interlocuções mais bem realizadas de Ana Cristina César com a poesia anterior a ela encontra-se na sequência de onze poemas chamados de "gatográficos", 1 escrita toda no começo de outubro em 1972 (alguns no mesmo dia) e publicada na edição póstuma Inéditos e dispersos organizada por Armando Freitas Filho (1985, pp. 62-73), como emblema de uma procura poética, presente em sua obra e na produção de outros autores de sua geração.

De imediato, o que eles apresentam de peculiar é a imagem recorrente do gato, e, além disso, ao pé dos sete últimos da série, a referência a poemas de Invenção de Orfeu como fonte de origem. No entanto, quem procurar a correspondência em Jorge de Lima, verá que a intertextualidade presente é sutil. Para começar, nos versos citados do poeta não comparece um só felino. A irregularidade métrica de Ana Cristina também não permite paralelismo completo quanto à construção, embora os últimos poemas sejam arremedos livres de soneto, e possamos muitas vezes perceber certas analogias no ritmo e no metro. Os primeiros quatro, embora não explicitem referência a Invenção de Orfeu da mesma forma que os outros, com certeza pertencem a quadro temático similar e iniciam a cadeia de imagens que a todo momento conflui, sem se confundir, com Jorge de Lima.

A comparação é sem dúvida temerária, tendo em vista que estes "poemas gatográficos" foram escritos quando Ana Cristina contava vinte anos. Talvez sejam os primeiros poemas "sérios" na sequência ainda adolescente de Inéditos e dispersos. Justamente cha- 
mam a atenção do leitor para o contraste de súbita maturidade. Há nova intensidade na procura poética e um diálogo desafiante e explícito com a tradição literária.

De fato, quem passeia os olhos pelos fatos de sua biografia, encontra Ana Cristina em seu segundo ano de faculdade de Letras (PUC, Rio), começando a vida profissional como professora de português e inglês, e participando de viagem ao Nordeste com intenções de pesquisa sócio-econômica, junto ao Cenpla. Enfim, trata-se do início da vida adulta. Esse tumulto contraditório da experiência transparece na composição dos poemas, que ela deixou inéditos, talvez porque ainda quisesse aprimorá-los. Ou, quem sabe, eles marcassem um momento de transição em sua poesia, como fecho de uma sequência que começara na infância e que aponta para uma virada evidente nos poemas posteriores. Depois deles, o organizador da antologia abre um outro capítulo de textos escritos a partir de 75 , já com as características estilísticas definidas que serão a marca da escritora até o fim. Os poemas do gato encontramse meio isolados da obra, embora as preocupações que desenvolvam acompanhem boa parte de toda sua poesia, imbricadas em outros textos que ela decidiu publicar.

Ao contrário, Invenção de Orfeu é a última floração de Jorge de Lima, o seu grande testemunho, de intenções épicas, escrito depois de muitos embates poéticos e existenciais com a religião, as ideologias, as amizades, os apelos da origem. Como foi que uma jovem poeta leu, compreendeu e interpretou algo publicado no ano de seu nascimento, e agora reescrevia aqueles versos sob o influxo de nova conjuntura histórica, e sob a inspiração de outra constelação de acontecimentos e teorias?

Enquanto o poeta mais velho construíra uma obra de fôlego, variada e complexa, o que temos para comparar são esboços assimétricos de uma voz que ainda experimentava por vezes canhestramente seus instrumentos de expressão. No entanto, apesar 
dessa significativa diferença, cremos que o cotejo é valioso pois os poemas de Ana Cristina manifestam suficiente força e qualidade para instigar o leitor crítico.

Ter escolhido Jorge de Lima como interlocutor, em plena década de 70 , demonstra, conscientemente ou não, a vontade de resgatar a atmosfera de sonho delirante do surrealismo, e sua construção entre livre e clássica, sem as peias da tradição da objetividade e concisão, tão proclamada nos anos 60 . Em diferentes momentos, ela nega sua vinculação às novas vanguardas e, em sua poesia vamos encontrar referências a Bandeira e Drummond dentre os brasileiros. Não me parece recusa doutrinária planejada, mas o desenvolvimento de uma poética paralela, que incluísse uma certa subjetividade, contraditória embora.

Como também, mais explicitamente, em seus textos teóricos, ela rejeita o "naturalismo engajado", que lhe parece um filistinismo pequeno burguês bem-intencionado. Até mesmo o nome com que foi publicada sua tese de mestrado sobre o filme documentário sobre literatura no Brasil, Literatura não é documento (PUCRJ, ed. Funarte, 1980) revela a ambiguidade de sua procura de estilo, contra um realismo gasto e auto-complacente, pretensamente revolucionário. Ao tentar definir o que seria o documentarista ideal, Ana Cristina propõe que seja alguém capaz de estabelecer uma "relação com a literatura como matriz de leituras possíveis." (p. 57). Assim também, os seus próprios textos, ao acercar-se de outros, procuram apropriar-se com bastante pessoalidade do estilo do a utor.

Se Ana Cristina decide-se pelo experimento, fá-lo sem ser fetichista: não se trata de apostar em procedimentos vanguardeiros por si mesmos. Há nela um entusiasmo da leitora e uma reconstrução pessoal da tradição que lhe permite afinar a voz na literatura anterior sem perder a liberdade do risco. Tenta atingir um tom que oscile entre a empatia emotiva das correspondências e a análise 
irônica, sofisticado e debochado, estetizante e espontâneo, provi ndo de muitas influências: mistura de tintas para expressar algo novo. A forma de aparência inacabada, tão comum àquela época, revela uma insatisfação não preenchível: o sentido é desdobrado em metonímias que não se perfazem. Recusa à "Palavra que não mexe mais no barril de pólvora plantado sobre a torre de marfim."

Há muito a pensar a respeito desses poemas, seja na relação com Invenção de Orfeu, seja como meditação sobre as dificuldades de expressão da época.

Em primeiro lugar, sabemos que um dos aspectos mais interessantes do mito de Orfeu foi sua ousadia de adentrar o Hades para buscar Eurídice. A confiança de vencer a morte, embora baldada pela ansiedade, não anula o gesto de coragem para tentar resgatar a amada. A memória amorosa, que a tantos poetas perseguiu e foi razão de seu canto - dentre eles Poe, que também não cons egue ressuscitar a bela Lenora (citada várias vezes em Invenção de Orfeu ) - intenta, ao menos pela cadência do canto, criar a atmosfera da repetição ritual e apaziguar as feras (inclusive, quiçá, as interiores), propiciando uma atmosfera de reunião - passageira embora - entre homem e natureza. $O$ poeta clama pela transcendência, através das figuras do amor e da fala poética: "Mendigo de pedir retorno a ser, ó Deus!/E peço-te Lenora, e peço-te meu canto!"' (Invenção de Orfeu, Canto VII, VI).

Em sonetos e outras formas poéticas, admiráveis pela simetria arquitetônica e pelas metamorfoses contínuas entre natureza e cultura, em que forma e fundo se harmonizam para melhor realçar os procedimentos persuasivos, o poeta revela sua vontade demiú rgica de fecundar a eternidade na poesia, ansiando por elevar a pal avra até a origem cósmica e igualando o poder do poeta ao poder do espírito criador em sua manifestação de "natureza naturante".

Mas ... sabemos que Orfeu foi afinal dilacerado pelas bacantes dos montes da Trácia onde tocava. Confundido com um 
animal, não foi poupado do delírio das mênades. No fracasso final para pacificar a auto-destruição pela harmonia musical, podemos reconhecer o ponto de partida do questionamento da arte dos anos sessenta e setenta, em sua recusa a construir objetos eternos e formalmente perfeitos, que vençam simbolicamente a morte.

A procura da palavra instauradora e total em Jorge de Lima é retomada por Ana Cristina como distância e perda, na qual a po esia dificilmente é transfiguração. Torna-se mais conturbada a passagem da vivência do corpo para a expressão pelo discurso, assim como o movimento contrário: do nome para a coisa. Esse intervalo é mimetizado pelos saltos do gato, que não se deixa transcrever com facilidade. $O$ conflito entre o empenho do poeta para forçar o gato para dentro do poema e a recusa deste em ser capturado pela representação, aqui chamada de "desenho", é bastante ambíguo. O desejável seria que os traços fossem feitos pelas próprias unhas do gato, e a poeta a ele se incorporasse, até chegar ao gato vivo e pa rticular: não mais um símbolo ou metáfora, mas apenas o ser gato. A vontade de fazer as coisas virarem palavras e vice-versa é tanto mais intensa quanto a descontinuidade e o isolamento do mundo do poeta se fazem mais agudos, agora sem forças mágicas, lutando corpo a corpo com cada pedaço do mundo, e vivendo "pânicos felinos". Imprimir de novo a linguagem no corpo, presentificar as coisas encarnando-as, também o quer a poesia de Ana Cristina, que dispende muita energia na tentativa, pois maiores se tornaram os obstáculos. Mas, ambos os poetas partilham o desejo do conhecimento inaugural (ou co-naissance, como sugerem Claudel e Maritain, bem conhecidos por Jorge de Lima) e querem voltar às origens para melhor investirem-se dos poderes criadores.

Se, porém, em Invenção de Orfeu, o eu lírico parece atravessar noites atormentadas, nas quais brotam mares de imagens a reunir em casamentos insólitos os seres e a consciência, há, no entanto, uma crença profunda na possibilidade de reunião de palavra e ser, 
hoje em crise, voltando-se o poeta para um tempo mítico, que se localiza na infância mais remota ou no futuro profético. Veja-se quantas vezes o verbo quer transmutar-se em corpo, em ser nascente, como o leite da vaca que mana da origem, "leite profundo" de onde germina a flor, a fonte, a memória: a nova palavra que infunde vida aos calendários frios (leiam-se os esplêndidos poemas XV e XVI do Canto I). Um Orfeu pós-romântico (portanto, subjetivado, contraditório) tenta superar a descontinuidade entre vida e morte, cicatrizando as rupturas do tempo, enlaçando o outro pelo canto, retomando amorosamente a infância, fazendo vibrar magicamente todos os seres na consonância da música.

É bem verdade que a linguagem profusa do poeta não sugere nenhuma totalidade de sentido, tanto que ninguém até hoje ousou interpretar Invenção de Orfeu como uma unidade simbólica. No livro $O$ engenbeiro noturno, Fábio de Souza Andrade reforça a idéia da "impossibilidade da epopéia" que a própria tentativa de Jorge de Lima atesta. Nele se alternam a fascinação com a volta a um estado inaugural mítico e o medo de perder a consciência dividida que a modernidade trouxe. O navegante inspira-se em Ulisses, Enéias, Vasco da Gama ... mas também no barco bêbado de Rimbaud.

Já Ana Cristina é atravessada por funda desconfiança na c apacidade do discurso de ressuscitar a vida, ou dar à luz qualquer ser que venha das entranhas. Ao cifrar o gato ("gatografar"), transformando-o em palavra, sabe que perdeu o contato direto com o bicho concreto: "o nome morto vira lápide/ falsa impressão de ete rnidade".

Ao retomar, vinte anos depois, imagens de Jorge de Lima, num momento internacionalmente qualificado de "pós-moderno" (em que vão se perdendo as certezas "racionais" da modernidade sem a compensação da retomada da fé tradicional), e ainda por cima, num Brasil abafado pela repressão, compreende-se o porquê de sua perplexidade e impotência em relação à palavra. Dividida 
entre a "vida em si" e a "escrita", sua poesia faz-se por metalingu agem, em mediação auto-irônica.

Assim, essa sequência de poemas faz uma revisão de Jorge de Lima acentuando um aspecto latente em sua obra. O que lá era mais ou menos recalcado, aqui é explorado a ponto do crítico Ítalo Moriconi supor que os poemas gatográficos seriam, na verdade, um inverso paródico de Invenfão de Orfeu, "disfarçado pelo gesto amoroso da fusão intertextual no pastiche"(1996, p. 98). Embora este seja um momento possível da leitura, preferimos, neste particular, seguir a esteira de M. Lúcia Barros Camargo, que encontra nas categorias de intertextualidade de Genette a definição da "paródia séria", em que pode haver transformação do texto sem intenção satírica.

Esta relação com a literatura anterior está em Ana Cristina, quando se inspira em outro poeta brasileiro (e, indiretamente, em Eliot e Baudelaire), quanto no próprio Jorge de Lima, que desejava recriar para o espírito moderno episódios d' Os Lusíadas de Camões, e aludia a Virgílio, Dante, Milton, Tasso, e alguns outros. Como já foi provado por vários estudiosos de Invenção de Orfeu, nele descobrimos em muitos momentos, o método de composição por montagem em mosaico, ou o palimpsesto, em que o texto base é em parte copiado, em parte alterado, constituindo nova fusão. ${ }^{2}$ Dessa forma, a influência de autores do passado é reatualizada na poesia, tornando-se presente, e amalgamando-se perfeitamente, já composta em novo contexto pela imaginação do poeta. 


\title{
À procura de um fio de leitura geral dos poemas:
}

Os poemas são para nós uma ferida.

\author{
Cachoeira \\ de repente alguém diz a palavra cachoeira \\ e ela se medusa \\ insolúvel \\ intimidade \\ piche insolúvel \\ negro. \\ ("Contagem regressiva", Inéditos e dispersos)
}

Vamos começar nossa análise mais detida comentando a lguns destes poemas de Ana Cristina e comparando-os aos referidos de Jorge de Lima. ${ }^{3}$ Seria traiçoeiro e domesticador tentar uma interpretação cabal, um "close reading" amarrado do começo ao fim, pois a coesão aqui se abre para a contradição e o inconcluso. Te ntaremos uma aproximação através da "cumplicidade inimiga" que Ana Cristina pede ao seu leitor. As imagens são por vezes enigm áticas e mesmo contraditórias. A sugestão indeterminada de sentidos faz parte do jogo, especialmente num mundo de fragmentos da consciência em que não existe um grande vetor de direção coletiva.

Observe-se o alexandrino, o peão quarto e o uso da segunda pessoa do singular que imprimem certo tom solene à abertura do primeiro dos poemas:

\section{Localizaste o tempo e o espaço no discurso que não se gatografa impunemente. \\ É ilusório pensar que restam dúvidas e repetir o pedido imediato.}


O nome morto vira lápide,

falsa impressão de eternidade.

Nem mesmo o cio exterior escapa

à presa discursiva que não sabe.

Nem mesmo o gosto frio de cerveja no teu corpo

se localiza solto na grafia.

Por mais que se gastem sete vidas

a pressa do discurso recomeça a recontá-las

fixamente, sem denúncia

gatográfica que a salte e cale.

Embora os sentidos últimos desses versos pareçam imposs íveis de alcançar plenamente, pois o leitor não tem todas as referências necessárias, uma impressão geral predomina, reforçada pela leitura do conjunto dos poemas seguintes.

Há uma tensão entre o "discurso", o "nome morto", a "grafia" - como formas de "localizar", "prender", "recontar" - e as "dúvidas", o "cio exterior", "o gosto frio de cerveja no teu corpo", as "sete vidas"... Em contraposição à escrita que inscreve em "lápide", ignorando os "pedidos imediatos", para "recontar fixamente", criando uma "falsa impressão de eternidade", haveria outra forma de mimetizar o real da vida e do corpo, através da gatografia, que poderia denunciar a "pressa do discurso", saltando o intervalo, soltando o reprimido e calando a imposição do arranjo artificial.

Paradoxalmente, seria talvez necessário o silêncio atento à vida, ou a imersão nela, para alcançar o gato, pois os nomes e letras não representam de fato os seres, que ficam submergidos em sua verdade íntima. $O$ saber apressado e preso do discurso falsifica a impressão do real. O tempo e o espaço, formas abstratas de percepção, se distorcem ao serem concretizados em palavras. A escrita pode sufocar o acesso direto à experiência. Nenhuma sensação corporal consegue exprimir-se através de uma lógica exterior ao 
discurso. A linguagem é figurada como grade que impõe sua própria estrutura sobre a existência (e aqui a poeta apresenta várias imagens: "o nome morto vira lápide,/falsa impressão de eternid ade", "nem mesmo o cio exterior escapa/ à presa discursiva que não sabe", "nem mesmo o gosto frio de cerveja no teu corpo/se local iza solto na grafia"). Como se estivesse enredado numa armadilha absurda, o eu lírico conclui que a linguagem se sobrepõe às tentativas de fuga. A gatografia, como alternativa, denuncia mas não co nsegue calar a "pressa discursiva" tirana, simulacro que fixa e computa os movimentos vitais.

O segundo poema também aprofunda essa contradição:

O nome do gato assegura minha vigília

e morde meu pulso distraído

finjo escrever gato, digo: pupilas, focinhos

e patas emergentes. Mas onde repousa

o nome, ataque e fingimento,

estou ameaçada e repetida

e antecipada pela espreita meio adormecida

do gato que riscaste por te preceder $e$

perder em traços a visão contígua

de coisa que surge aos saltos

no tempo, ameaçando de morte

a própria forma ameaçada do desenho

e o gato transcrito que antes era

marca do meu rosto, garra no meu seio.

Atento, o eu lírico observa o nome do gato que não o deixa dormir porque este, por sua vez, morde seu pulso. O bichano está distraído, portanto, este comichão para escrever que a pinçada 
perto da mão, na sede vital, provoca, não é gesto deliberado e proposital. Há intimidade entre eles, como na relação de Baudelaire com os felinos. O nome provoca o poeta a ver a coisa em sua inte $\mathrm{i}-$ reza, num flerte entre sedutor e agressivo.

Em vez de escrever o nome, enfrentando diretamente o ser, o que aparentemente seria facilitador, o eu lírico resiste e prefere um caminho de desvios, talvez para evitar o aprisionamento do gato. As partes tateiam o todo, sem apaziguá-lo taxando-o imediatamente por uma palavra possivelmente redutora: "pupilas, focinhos/e patas emergentes". O que comparece são os olhos em seu brilho, a boca que mordisca e cheira, os movimentos dos pés...aquilo que se aproxima.

Mas o nome negaceia, não se deixa capturar. Como em "Procura da Poesia", de Drummond, as palavras não se abrem sem luta e sem a chave certa. O nome é "ataque e fingimento": tudo faz para não entregar sua essência aos que não sabem desvendar seus mistérios ou defender-se de seus golpes.

O gato precede o escritor, e este talvez só se constituirá como autor quando souber transcrevê-lo. Inverte-se a relação entre "sujeito" e "objeto", pois a tentativa de mímesis nada tem do "recolhimento da emoção na tranquilidade" wordsworthiano: ao co ntrário, é o gato o elemento ativo que espreita, sonso, como quem caça. Ele se recolhe para atacar, fazendo a poeta "perder em traços a visão contígua/de coisa que surge aos saltos/no tempo, ameaçando de morte/a própria forma ameaçada do desenho". A distância, que poderia levar a experiência sensorial à palavra representativa anula-se, e o gato esquiva-se de ser nomeado como objeto parado e inteiro: o que o observador pode ver são movimentos - mais o devir e o fluxo do que o espaço descritível. O nome decompõese metonimicamente em partes contíguas, visto ser impossível aga rrá-lo. Ele destrói sua forma gráfica para recuperar o corpo vivo da primeira experiência de relação visceral: "marca do meu rosto, ga r- 
ra no meu seio" - signos da anulação de qualquer intervalo entre poeta e mundo - tão entranhado que não pode ser visto com inte ireza - tão "um-no-outro" que ambos são ameaçados na qualidade de mônadas com a faculdade de criar laços analógicos metafóricos: apenas o fragmento é vislumbrado, dado que a principal relação não é mais a do olhar e sim a do ataque corporal. O mundo nega-se à vontade e à representação.

O quinto poema, em diálogo indireto com Invenção de Orfeu, está eivado por essa contradição entre ser e palavra:

\section{O gato desaparece do poema}

feito de leitura ensangüentada e surda.

Coisa química transpondo o louco

crescimento endurecido.

Ruptura anseios de ter gato

e escapá-lo das cabeças das medusas

e desenhá-lo nas escarpas dos seus pulos

e neles arrastar o sal espesso

dos seus pelos umedecidos pela espera, e a dor

de não poder cindir a noite,

nem o dia,

nem estranhamente sumir às vistas

do monstro e sem saber

fluindo entrar nesse poema.

O poema, assassino, deseja de alguma forma neutralizar o gato como objeto, tirar seu sangue, e dele fazer surda leitura, evitando a distância do ver e ouvir, para melhor possui-lo. Quem sabe recriando-o quimicamente, conseguiria aprisioná-lo em diagrama de letras, "transpondo o louco/crescimento" de forma endurecida.

A "ruptura" da relação talvez cômoda mas mentirosa entre sujeito e objeto seria a possibilidade de impedir que o gato fosse 
imobilizado para o retrato (como fazem as cabeças das medusas, que petrificam com o olhar). $\mathrm{O}$ anseio de "desenhá-lo nas escarpas dos seus pulos", mergulhando em sua natureza, numa escrita análoga ao sal que quase se dissolve na umidade da espera por esse momento, salvando o gato do monstro paralisante, é baldado. A dor de não poder penetrar dia e noite, e de reconhecer-se sempre separado e consciente de si, impede o delírio embriagante da união completa, do que se esquece, e, com perfeita naturalidade, pode "sem saber/fluindo entrar nesse poema."

Ao ler Jorge de Lima pelo olhar de Ana Cristina, percebemos indícios, também nele, do medo e do desejo de alcançar, pela palavra poética, os sonhos inconscientes, aquilo que é disforme e matricial. O primeiro poema do Canto IV, que se chama "As aparições", citado como inspirador dos versos acima segue assim:

Um monstro flui nesse poema

feito de úmido sal-gema.

A abóbada estreita mana

a loucura cotidiana.

Pra me salvar da loucura

como sal-gema. Eis a cura.

$O$ ar imenso amadurece, a água nasce, a pedra cresce.

Mas desde quando esse rio corre no leito vazio?

Vede que arrasta cabeças, frontes sumidas, espessas. 
E são minhas as medusas,

cabeças de estranhas musas.

Mas nem tristeza e alegria

cindem a noite do dia.

Se vós não tendes sal-gema,

não entreis nesse poema.

A construção dos dois primeiros versos dos poemas é similar. Em ambos, conserva-se a ambiguidade sobre o sujeito da segunda frase. Será que é o monstro ou o poema que seriam feitos de "úmido sal-gema"? Ou será que é o gato ou o poema, que são compostos de "leitura ensanguentada e surda"?

Mas a direção do poema de Jorge de Lima faz pensar que o poeta acredita na possibilidade de transpor ao menos alguma qualidade criativa de seus sonhos para a vida. O sal-gema salva da lo ucura e, embora o rio corra num leito vazio e leve tudo embora de roldão, e que, por fim, seja um monstro o que flui no poema, há uma permeabilidade, pequena embora, entre mundo mental e realidade. "Se vós não tendes sal-gema,/não entreis nesse poema."... como se este sal que brota do fundo da terra nordestina fosse a essência indissolúvel, mesmo quando todo o resto alui. Tristeza e alegria passam sem alterar o curso da noite e do dia, cabeças de medusa - musas da alucinação - são arrastadas, a natureza segue seu curso, só permanece o sal da terra, tempero compartilhado entre poema e leitor.

Já no poema de Ana Cristina, resta apenas o desejo de conseguir isso por meios mágicos, empáticos e animistas. Mas, sabe-se, desde o início, que o gato desapareceu, e que a leitura é ensanguentada e surda, como se fosse necessário morte ou apagamento para fazer nascer o poema. 
Ana Cristina recupera a vontade de fazer fluir o corpo para dentro do poema, esse leito seco do rio, cheio de medusas que assombram o poeta. Seco como o Nordeste, em que o sal-gema é encontrado onde antes havia oceanos. As aparições precisariam de um amuleto de essências, que em sua mínima matéria conferisse realidade e sabor real ao simbólico - um resíduo quase invisível, como um espírito que habitasse o corpo. Mas "o mar secou" e não há mais como entrar no poema, nem com sal, nem com pulos, nem se escondendo dos monstros...

Talvez a comparação mais interessante seja a relativa ao sétimo e o oitavo da série, ambos inspirados no mesmo poema de Jorge de Lima - no Canto I, o XXII:

O céu jamais me dê a tentação funesta

de adormecer ao léu, na lomba da floresta,

onde há visgo, onde certa erva sucosa e fria, carnívora decerto o sono nos espia.

Que culpa temos nós dessa planta de infância, de sua sedução, de seu viço e constância?

Minha cabeça estava em pedra, adormecida, quando me sobreveio a cena pressentida.

Em sonâmbulo arriei as mãos e os pés culpados dos passos e dos gestos em vão desperdiçados.

Despi-me de outros bens, de glória mais modesta: restava-me por fim a minha pobre testa 
confundida com a pedra, em meio da floresta.

Que doces olhos têm as coisas simples e unas

onde a loucura dorme inteira e sem lacunas!

Agora posso ver as mãos entrecruzadas

e as plantas de meus pés nas entranhas amadas, nesse início que é a clara insônia verdadeira.

Ó seres primordiais que sois testa e viseira, restituo-me em vós, sangue e máscara vividos,

desejo de esquecer tempo e espaço existidos, e em vós e em vossa paz meus solilóquios paro-os,

penetro-me do Verbo em seus silêncios claros, invisto-me de vós, vossa fronte me espia

através dessa pedra em que nasce o meu dia.

Há um entrelaçamento do homem com a natureza, um enraizamento profundo na infância, no sonho, e a concomitante pe $r$ da da razão, numa volta ao tempo primevo - um adormecer no começo da vida: "desejo de esquecer tempo e espaço existidos"

A floresta, o céu, as plantas, são, nestes versos, partes da totalidade de onde saímos na primeira infância e que nos seduzem para a unidade primordial, anterior à consciência do tempo e do espaço, até mesmo pelo eco aliterativo do som sibilante: uma atração pela paz e pelo doce sono, perigosa porque irracional, pois confunde homem e natureza.

$\mathrm{O}$ eu lírico gostaria de adormecer na floresta e virar pedra. Ao mesmo tempo, tem medo dessas plantas carnívoras, esse visgo 
que sente como se fosse um pecado original. ${ }^{4}$ Dormir no chão da floresta é um abandonar-se, o que comporta serenidade e aconch ego mas também a angústia da desproteção de um lugar ermo, onde se retorna à infância mais primitiva. Tem-se a impressão de dois símbolos opostos e complementares: o nascimento e a morte juntos, como se o poeta pudesse voltar à terra mãe, com o risco do apagamento da consciência, porque a pedra é um pouco o umbigo das coisas. Digamos que é o momento edênico: como no útero materno, aqui percebe-se o desejo mais regressivo, em que a anulação do eu pode ser o renascimento para a beatitude.

N' "A Interpretação dos Sonhos", Freud salienta que as imagens são sobredeterminadas, isto é, os seus vários aspectos não podem ser separarados. Juntas, a tentação funesta, e a liberdade de soltar as mãos e os pés... Seus membros são os culpados por suas ações e deslocamentos. Precisa livrar-se deles para sentir absoluta tranquilidade. E para onde ele vai, afinal, após passar por essa morte simbólica? Chegar às entranhas amadas, até tornar-se pedra.

Sobra a cabeça: testa e viseira são paralelos a sangue e má scara. Nos seres primitivos a relação entre ser e aparecer é sólida: a testa e viseira constituem o mesmo. Voltando à origem, apaga-se todo movimento da vida. Os seus solilóquios interiores, seus gestos e até as palavras, tudo ele vai arriar para voltar a uma paz fund amental. Mas ele está com medo disso, quando diz que "a loucura dorme inteira e sem lacunas", pois vai imergir pelo sono e pelo delírio, no inanimado inconsciente. A lacuna é própria do pens amento, e ele quer acabar com essa divisão, fundindo-se completamente.

A seguir: "visto-me de voz". É o Verbo, com letra maiúscula, representando o poder de criação. Como em tantos outros poemas, aqui Jorge de Lima remete a Orfeu: seja por assemelhar-se a ele ao morrer, quando lhe resta só a cabeça cantante imortal, seja porque teve coragem de ir para o escuro inferior e voltar para o 
claro. Esse sono, ou pequena morte, conduz a um renascimento, e através dele o poeta consegue transmutar-se em Verbo, é investido do dom da canção, como o deus, entre pagão e cristão.

A apropriação do poema por Ana Cristina César é lateral em relação a Jorge de Lima. Se, no poeta, há volta ao tempo primordial, já Ana Cristina prefere viver a ansiedade perigosa da consciência da separação mesmo na tentativa de retomar o paraíso. A poeta sugere que essa reunião mística não pode acontecer pois não consegue esquecer a diferença, como um exílio. Em um, comunhão e glória, noutro, desgarramento, e esforços frustrados de - ao contrário - libertar-se do Verbo:

Nem agora posso ver minha vontade amada

de destituir-me dos inícios revividos

e esquecer o tempo e o espaço do discurso

como um gato que se apaga do caderno;

em ti espio teus ensaios

de silenciar os ossos removentes

e penetro tua testa onde se encrava

o sangue de arranhões das tentativas.

Nem agora posso ver minha leitura

e dela me afastar num salto único

sem ter donde fugir, isenta e clara.

Nem agora os verbos me consolam

e saltam como gatos desgarrados por cima dessas pedras que me inscrevem. 
Como Jorge de Lima, também a poeta deseja despir-se do próprio eu, ao que parece. Mas, não consegue apagar a figura do gato representado no caderno e voltar ao tempo zero, anterior ao discurso. Como fugir da leitura e, talvez, ser de novo junto às coisas, sem a separação que trazem as palavras?

O terceiro e o quarto dísticos referem-se a um "tu" - um outro - que poderia ser, quem sabe, o poeta de Invenção de Orfeu, que tentou, antes dela, chegar a esse Éden primevo. Ou, ainda, esta segunda pessoa é o próprio gato, em que ela se inspira para imaginar movimentos de libertação.

Afinal, o poema reconhece seu fracasso pois, ao contrário de Jorge de Lima, os verbos (no plural e com letra minúscula, como designadores de muitos pedaços do mundo, incontroláveis, "desgarrados") não a transfiguram para a criação órfica do dia pleno. São eles que "saltam"... "por cima dessas pedras que me inscrevem." As pedras tornam-se o sujeito da ação, talvez comandadas pelos "verbos". São elas que inscrevem o eu lírico, sob elas coloc ado, sem poder fugir da representação dada para a pureza inicial.

Eis o oitavo, que, como dissemos, também se refere ao mesmo poema de Jorge de Lima:

\section{Os gatos jamais me dêem a sensação \\ à toa \\ de ter adormecido antes do perigo \\ onde há carne, e líquido, e suor lento}

engolindo a vontade da Palavra.

Que culpa tenho deste sono que se origina

antes de mim,

na dúvida de saber que sorriso fez 


\begin{abstract}
os gatos de músculo me atentando
me querendo sem roupas e ao frio

dos telhados
\end{abstract}

\title{
escrevendo as coisas felinas confundidas \\ e seus pulos imitando sem desenho \\ "onde a loucura dorme inteira e sem lacunas".
}

Ana Cristina substituiu o elemento bucólico vegetal pelos gatos. A tentação do sono delirante e do apagamento da consciê ncia não é mais a volta ao seio materno mas impulsos sexuais, numa exposição do corpo e da mente ao frio, ao lá fora. A relação com o Verbo, solene e demiúrgica em Jorge de Lima, torna-se uma fome entre reprimida e desejada.

Quando o poema de Ana Cristina confere aos gatos energia sexual, eles querem não só apropriar-se da palavra como do corpo da poeta. Outro aspecto da fenda entre o sujeito e o outro materi aliza-se na falta de sono, no desconforto físico, no perigo tentador.

O tormento sem resolução também se reflete na construção de sentido obscuro, em que parece haver duas vontades convive ndo: uma, clara, que afirma a predominância da vigília, convivendo com o risco e a sedução sem fugir; outra, incontrolável, pois o "sono [...] se origina/antes de mim," e os pulos felinos não podem ser representados por desenhos pois expressam as forças irracionais do desejo. Entregar-se aos gatos seria incorporar a própria coisa que se quer descrever e, então, perder o poder da escrita, a alteridade da lacuna.

Tanto o paralelismo de construção, quanto os deslocamentos e aproximações de palavras, e até, em certos momentos, o ritmo similar, mais acentuam a dificuldade de coesão do poema de Ana Cristina César em relação à força da construção rimada, simétrica, de Jorge de Lima, como alguém que não sabe pintar e repete, 
quase sem arte, o quadro do mestre, mas, ao fazê-lo, revela a angústia e as sombras do que parecia exposto com majestade e clareza. A tensão relacionada à tentação da entrega à palavra e à coisa, presente em Jorge de Lima, mas nele sublimada pela transfiguração da entrega total, aqui agudiza-se e rompe os sentidos encadeados.

O próximo poema de Jorge de Lima a que se refere Ana Cristina (Canto I, XVIII) aborda imagens de fertilização ou da atração entre os princípios masculino e feminino nos reinos vegetal e animal, com a inspiração surrealista do discordia concors.

Éguas vieram, à tarde, perseguidas, depositaram bostas sob as vides.

Logo após borboletas vespertinas, gordas e veludosas como urtigas,

sugar vieram o esterco fumegante.

Se as vísseis, vós diríeis que o composto

das asas e dos restos eram flores.

Porque parecem sexos; nesse instante,

os mais belos centauros do alto empíreo, pelas pétalas desceram atraídos, e agora debruçados formam círculos; depois as beijam como beijam lírios.

Seriam as éguas perseguidas pelos centauros? Será que o encontro de borboletas e esterco assemelhar-se-ia à imagem do sexo genital - tão próximo ao lugar da defecação? Então, haveria uma transfiguração perpétua, no ciclo natural, entre baixo e alto (fezes e lírios) que levaria a uma impressão de totalidade, ainda que pela analogia onírica? 
Também os dois últimos da sequência gatográfica de Ana Cristina dizem buscar neste poema inspiração. Mas, embora isso pareça claro em relação ao segundo deles, no caso do primeiro, temos a impressão de que se tratou de um deslize de notação, pois ele (o décimo da sequência) segue, em sua estrutura geral, o Soneto XXXIII do Canto I, tal qual o nono poema. Antecipa o próximo da série, que mantém com ele uma relação de progressão conclusiva.

Este poema, o décimo, concebe a relação com o gato como uma gênese a partir das entranhas, em que o poeta origina-se do animal e vice-versa:

tu queres gato: tira do teu ventre morno medida de tua garra,

o formato e as unhas te fazendo, tuas certezas, teu único sonho, botas $e$

cobertas que também desfazem teu salto

e se apronta para sobrevoar o campo alheio

e se lançar meio tigre sobre as marcas

que não sabes nem sabes repousar, e os gemidos

de fome em gato não ouças, mas vive

os cantos da casa e os pelos amedrontados

e a ameaça acordando o nome gasto

e se deita depois num lento revirar ignorado, torna a escrita e o desenho que ressonam desconhecidos traços te seguindo.

Há uma interpenetração entre poeta e gato que vai além do 216 eco de "formato" e de "nome gasto", pela qual o eu lírico procura 
saltar como um felino, após ter gestado em si o gato e, quiçá, tran sformado-se nele. Suas próprias garras arrancam do ventre o gato, avançando sobre "o campo alheio", enfrentando a "ameaça" de encarnar-se gato. Afinal, a escrita e o desenho dormem, apaziguado o desejo de conhecer, pois agora o poeta conseguiu passar para o lado do gato, e vive o inverso: são os rastros incompreensíveis da escrita que o seguem. Alcançar um estado de não saber, como o sono da coisa ignorante de si, parece a forma de melhor exprimi-la, em que a escrita é deixada para trás, uma vez que o eu lírico ass umiu o ser mesmo de seu objeto. O nome, a escrita, o desenho, os traços... tentam segui-lo, enquanto o poeta vive o gato.

Para concluir, o poema seguinte de Ana Cristina extrai o princípio da criação: os gatos vêm, à noite, procurar seu criador, invadindo os restos do imaginário e se libertando, como que para alcançar um estado superior, além da linguagem:

Gatos vieram, à noite, perseguindo,

deitaram seu hálito sobre o sono.

Logo após o salto imaginário

de fatos e palavras misturados

vieram saber de cada gato

o gato que os soubesse, e a todos

compusesse dos restos de desenho

e traços e sexos procurados.

Porque nesse instante perdeu-se

a voz que os miasse e desse forma

e de gato se fizesse sem engenho

e deformando-os em bichos nunca vistos, não mais linguagens perseguidas, mas gato somente se lambendo. 
Querem, finalmente, ser apenas gatos, sujeitos de si. Para além do símbolo poético, agora eles tornaram-se "não mais lingu agens perseguidas/mas gato somente se lambendo." Será uma conquista do eu lírico esta possibilidade de perder a voz e a forma para alcançar as coisas e seres em si mesmo?

Pensando bem, o espírito desses últimos dois textos têm de fato relação com o último poema escolhido de Jorge de Lima. Tanto um quanto outro dele derivam aspectos da alquimia, em que o baixo se transforma em alto e o casamento dos elementos mais díspares pode ser fecundo e totalizador. Há sempre uma crença animista de que tudo no universo corresponde-se e sublima-se pelo poder do Verbo ou do espírito criador, em analogia metafórica. Os contrários em tensão resolvem-se dialeticamente, dada a harmonia - inclusive formal - de sua construção. Já em Ana Cristina, há uma "desmetaforização", passando-se do sono e da imagem para a co isa: o gato concreto, que se construiu a partir dos restos de desenhos, não pode mais ser representado, pois tornou-se a origem de si mesmo. A voz e o engenho se perderam. Ele escapa da mimese ao se metamorfosear em "bichos nunca vistos", que a linguagem não alcança, pois agora ele é pura matéria.

Para Ana Cristina, a tentativa de representação dá-se, em todos os poemas, por meio de quedas, saltos, unhadas - sangue e pelos: o poeta imita e enfim recria o gato e este, por sua vez, pula no discurso, ferindo as letras, tentando "sem saber/fluindo entrar ne sse poema.", arrastando sal pelas linhas dos versos... como em "As aparições", do Canto IV da Invenção de Orfeu, em que o eu lírico come monstros feitos de sal-gema, talvez para incorporar a loucura criadora e encontrar a quintessência da matéria: aquela que dá sabor à palavra. O "salto futuro do poeta" que gera "montanhas/e desenhos e escritos" de Ana Cristina remete ao "fogo desabroch ado" de Jorge de Lima, a dar à luz um dilúvio de seres e vozes. 
Mas, adiante, nesta conversa misteriosa entre dois poetas, a mais jovem ecoa, mas possivelmente discorda, do soneto XXII do Canto I. Retomando o que já dissemos acima, naquele poema, o eu lírico é tentado a adormecer na floresta e a se confundir com os seres primordiais, renascendo em pedra, esquecendo tempo e espaço. A poeta lamenta-se, por sua vez, porque não pode entregar-se à natureza inconsciente, apesar do "sangue de arranhões das tentat ivas". As pedras de Jorge de Lima penetram-no "do Verbo em seus silêncios claros", incorporando-se ao corpo e à mente do poeta. Já em Ana Cristina, em meio à crise aguçada da palavra: "Nem agora os verbos me consolam// e saltam como gatos desgarrados/por cima dessas pedras que me inscrevem." Em contraposição à força profunda de criação pelo sonho, pela memória, pelo fazer poético, que encontramos em Jorge de Lima, há, nesta série de poemas "gatográficos", uma consciência da dificuldade da escrita, proporcional à negação dos seres em se deixarem representar. Como se reconhecesse que a pessoa do poeta e o mundo ao seu redor estivessem fora do alcance do poema, e, apesar do esforço de captura, a realidade fosse o sujeito e dominasse o objeto-poeta. Este, que a persegue, submete-se ao seu fascínio e ao mistério do irrepresentável.

Há algo que apenas se entrevê em Ana Cristina, em seus "diários" fugidios, como se as referências diretas aos fatos e toda descrição estivessem interditas pela dificuldade da representação fruto significativo da crise da própria voz. Lembrando Octavio Paz, "o mundo como imagem evaporou-se. Toda tentativa poética se reduz a fechar o punho para não deixar escapar esses dados que são o signo ambíguo da palavra talvez."(Lima, 1994, p. 236).

Todos os poemas da sequência inscrevem-se sob esse "signo ambíguo" que lhes confere um destamanho, um desajeitamento, uma certa incoerência - sinais dos sucessivos saltos irregulares para empenhadamente alcançar algo em perigo de se perder, talvez: a 
espessura do sal-gema poético. Embora seja claro nos escritos de Jorge de Lima um projeto épico e religioso, aparentemente confiante no poder de regeneração do mundo pela palavra, a pujança do orfismo é atravessada por estilhaços de mitos que desabam e pela angústia da loucura. A arquitetura e a coesão, porém, ainda que tantas vezes obscuras, não se deixam arrastar completamente para a confusão. Mesmo elaborando seus poemas a partir do imaginário onírico, configura-os como uma narrativa com alguma concaten ação. Mas, também ele compôs Invenção de Orfeu em período conturbado para si mesmo e para o mundo. O pós-guerra é um momento de reflexão sobre uma terrível crise da civilização. A perturbação está presente na raiz do tom esperançoso.

Já em Ana Cristina, as relações entre poeta e mundo, arte e natureza, são de descontinuidade ainda mais acentuada. Concomitante, o desejo de anular a distância deve-se ao dilaceramento provocado pela alienação, que vai se intensificando. Ana Cristina ativa a linha, presente em Jorge de Lima, da negatividade própria da modernidade, que perde o equilíbrio entre forma e conteúdo, e do surrealismo mais radical, que almeja disseminar na vida o poder da arte.

Ambos invocam o espírito profético e apaixonado do lirismo romântico para falar em jorro, embora os dois deixem transparecer todo o tempo grande densidade de informação literária. Atualizam o surrealismo, trazendo para seu horizonte a comunhão erótica como força poética, criativa, assim como o contrário disso, que é o estranhamento - e, por fim a metamorfose contínua, o deslocamento metonímico digressivo em que um campo semântico evolve para outro, como na analogia onírica. O hermetismo é co nsequência dessa fluidez das direções de sentidos semiconscientes.

Peter Burger, em seu Teoria da vanguarda, critica essa entrega ao acaso como uma volta às leis da natureza, o que ele considera uma regressão em relação às imposições sociais. $\mathrm{O}$ inconsciente 
não pode ser igualado ao reino da liberdade, diz ele. Condena igualmente a postura similar no gesto dito espontâneo da "action painting" ou na anulação da vontade de John Cage. Mas, nos três casos, o que se busca é uma energia criadora não condicionada p elas regras da arte. Não há dúvida de que se trata de uma contestação pois a volta ao sonho ou à natureza reflete o desejo de recriar o mundo, livre das peias da convenção, ainda que na esfera das rel ações íntimas. $\mathrm{O}$ retraimento à esfera privada reflete, antes de tudo, uma distância tão grande entre sujeito e mundo que o poeta precisa reencontrar primeiro o seu próprio eu. Houve um deslocamento da tônica, em que se acentuou principalmente um aspecto antes subordinado a um projeto maior.

Ao retomar os experimentos próprios das vanguardas, como o uso de ready-mades e colagens e procedimentos disjuntivos, Ana Cristina produz um texto misturado, sem o tom profético do demiurgo. Tanto na forma quanto no conteúdo, Jorge de Lima é mais clássico e elevado - mesmo quando incorpora a alucinação e o excremento à poesia - pois sempre procura o sentido órfico e simbólico. Em Ana Cristina, a dúvida solapa a possibilidade do sublime.

Além disso, o próprio exílio interior que marca sua geração contrasta com a presença de uma comunidade de leitores identificável, no caso de Jorge de Lima. Intelectuais sensíveis ao modernismo e à temática mística rodeavam o poeta, tecendo uma rede de apreciadores que o apoiava criticamente. No caso da obra de Ana Cristina, embora houvesse um público ligado à universidade e à criação de poesia que lia e, quiçá, comentava seus poemas, percebese uma carência própria daquele momento histórico que se infiltra na própria construção de seus poemas. A particularização do interlocutor reflete-se na sensação de fechamento do destinatário do ato poético. A reiteração da forma do diário e da carta (e o tema do carteiro que perde e mesmo enterra a correspondência) relacionamse ao estreitamento da vida cultural. Perda e distância se dão ta m- 
bém nas relações semânticas inerentes ao poema, e se manifestam na falta de nexos claros entre nome e coisa, nome e corpo, nome e sujeito.

Convém lembrar que Jorge de Lima, no seu desejo de abraçar com a palavra a totalidade cósmica e a riqueza do sujeito, ta mbém trabalhou com a desproporção na função representativa da linguagem. A relação entre palavra e coisa nele vem abalada pela proliferação às vezes contraditória, por vezes vertiginosa, de símbolos polivalentes. Seu estilo, tantas vezes considerado "hermético" ou "barroco", caracteriza-se pelo desdobramento de metáforas em cadeia onírica. De todo modo, a diferença entre os dois poetas impõe-se. Jorge de Lima viveu uma cultura mitopoética de raiz bíblica e simbolista-surrealista que, como já dissemos, tinha confia nça no poder da palavra. Mas o gato de Ana Cristina radicaliza o dilema velado ao buscar o poema como um signo que almeja a ser coisa, como um movimento sempre inconcluso.

Já estava no surrealismo o projeto da arte vital que, lembra Lipovetski, aspirava a "reencontrar as fontes instintivas da expre ssão", sem descurar da pesquisa sobre a forma na arte. Entre a empatia mágica e a racionalidade analítica (des)equilibra-se a modern idade.

Em certa medida, Habermas acertou ao afirmar que a modernidade não esgotara seus projetos. Mas, não foi pela realização dos sonhos de justiça da razão iluminista que continuamos sob a mesma égide de questões e sim, talvez, pela exacerbação dessas mesmas questões que, em alguns casos, tornaram-se, na literatura, estilo refinado e procedimento retórico maneirista e, em outros, angústias antes esteticamente sublimadas, como no caso da "body art" e de muitas performances. A auto-consciência pode vir aco mpanhada de um sentimento de impasse, bem figurado nas tensões da poesia de Ana Cristina, que assim exacerba temas latentes em 222 Jorge de Lima. 
A questão que a poesia de Ana Cristina nos coloca tem rel ação com a própria compreensão da mudança de lugar do fruir estético (conforme nos adverte Adorno). Se, para Kant, a distância que aprecia mas não consome o objeto era a sua definição, aqui a i mperfeição referenda a busca de um objeto fora do poema e dos procedimentos comuns à escrita, colocando em crise o lugar do artista como demiurgo da imitação. A contemplação é essencial à imagem. Para abrir as coisas e transfigurá-las em "objetos inesgotáveis" (na expressão de Rilke) precisamos de certa amplitude. Mas o gato de Ana Cristina vai para o caminho oposto: um signo que a lmeja a ser coisa, ultrapassando o seu lugar na metáfora.

Se as palavras fogem e se esquivam, deseja-as mais do que nunca a poeta. Se querem voltar a ser nomeadoras, com força de Verbo, precisam ser de novo criadas. Continuar uma tradição sign ifica mesmo "make it new", conquistando-a para atualizar sua essência viva.

O gato tem pregnância simbólica e não pode ser facilmente representável. Escapa à rede de sentidos analítica e dos a priori de tempo e espaço porque é a carne em si mesma, a matéria inocente, a pulsão anterior à consciência, o ponto negro do corpo. Como capturá-lo a não ser entregando-se ao mundo em sua originalidade? Isso é impossivel e contraditório, assim, o gato não se torna um emblema claro, um feixe de sentidos, pois ele não se resolve, como uma incessante interpelação.

Malrieu, em suas reflexões sobre a construção do imaginário, observa que, através de figuras, o artista descobre seus próprios conflitos e pode utilizá-los para construir sentido. $O$ desejo, ao tentar captar para si o objeto, acha um correlativo - um tipo de síntese ou elaboração de algo novo. $\mathrm{O}$ extraordinário procedimento de Ana Cristina é apresentar este processo em estado de luta, em plena dissonância, quando ainda enfrenta a busca, tateante. 
Se a imagem advém da consciência da ausência, por ser fruto de uma construção mental que pressupõe a distância para se realizar, não haveria possibilidade de criar quando o objeto se impuse sse como um fato que não comporte as mediações da imaginação. Assim, os "poemas gatográficos" especulam sobre este paradoxo: alcançar o gato e entranhá-lo no poema seria perder o "analogon" imaginário próprio do símbolo (como o batizou Sartre).

Percebemos que a dificuldade de compreensão não parece subordinada a alguma inclinação preciosista mas, ao contrário, a esse experimentalismo destrutivo. Se há um relativo fracasso para alcançar uma forma de expressão que traduza com a coerência po ssível o que se pretende dizer, isso se deve à própria dificuldade da empreitada. As ambiguidades na construção sintática concordam com a indefinição do ponto de chegada. Lembrando Adorno, quando se refere a Valéry, aqui também trata-se de uma tentativa de construir algo que resiste ao fácil, para não trair seu anelo de verdade. Para ser fiel, a artista prefere "perecer no impossível", arriscando-se para melhor exprimir o (quase) indizível. A apreensão da totalidade do mundo tornou-se opaca na modernidade, e a arte deveria exprimir, pelo seu hermetismo obscuro, essa dificuldade.

Assim, considero que uma das maiores riquezas dos poemas "gatográficos" reside na dificuldade da forma, que mimetiza a tentativa de aproximar-se de um conteúdo reticente: a escrita da vida, em sua forma inconsciente.

Em $A$ teus pés, há um poema cujo começo imita um manual de retórica a definir os tipos de poesia da forma mais didática: "Os gêneros de poesia são: lírico, satírico/didático, épico, ligeiro.” E continua por aí, até o final, quando então interrompe a seca conceituação para introduzir o dilema da forma, que não deveria ser exterior à necessidade expressiva do poeta: 


\author{
olho muito tempo o corpo de um poema \\ até perder de vista o que não seja corpo \\ e sentir separado dentre os dentes \\ um filete de sangue \\ nas gengivas \\ ("Primeira liçào", pp. 58-59)
}

Esta lição já se encontra, de alguma maneira, no "Fedro" de Platão, quando Sócrates discute qual é, afinal, o sentido primeiro da retórica: se o conhecimento dos modos de elocução (para melhor apresentar os recursos persuasivos) - portanto, uma ligação com o conhecimento que não precisa ser amorosa - ou se, ao contrário, não seria absolutamente necessário incorporar aos procedimentos da criação de discursos a revelação da alma. Esta, por sua vez, dá-se através do amor ao corpo belo, que infla as asas internas. Somente a aproximação empática com o outro permite a verdadeira compreensão, enquanto a clonagem de formas pode ser mortal - pois substitui-se à vida.

Adorno, em suas primeiras obras (especialmente na Dialética do Esclarecimento) retoma de outro ângulo esta mesma questão, considerando a mimese que se entrega ao objeto como perigosa pois saboreia acriticamente o mundo, seduzida infantilmente pelo canto das sereias, das quais não se descola dialeticamente. $O$ processo civilizatório deve recalcá-la, mesmo ao custo de certa rigidez do eu, que propiciaria a constituição da identidade autônoma. ${ }^{5}$

Mas, nestes poemas, o eu lírico luta justamente pela "descriação" do eu, através da qual a poeta exacerba sua atenção ao outro, procurando misturar-se aos seres (figurados pelo gato), à busca de um olhar menos centrado na sua limitada consciência, para ganhar de novo o mundo que se distanciava. Ora, não há desapego sem dor, adverte-nos Simone Weil. E este é o momento para surgir a nossa poeta: pelo conflito entre a subjetividade e a expressão de um 
mundo mais amplo, ao qual ela quer se entregar com ardor, mas ainda com medo. Ela nos expõe com todos os vaivéns o seu dilac eramento, e daí advém a tensão destes poemas.

A impregnação das coisas, provinda de um afeto especial em relação a elas, seria o primeiro movimento de escolha do campo de atenção, que mobiliza os objetos: disso tratam esses poemas, como a apresentar um processo criativo em seus inícios, aberto para o nosso exame: o ateliê aberto, a matéria-prima, o embrião. Se, em Jorge de Lima, a cristalização da forma parece mais artística, aqui trata-se da perfeita expressão do inacabamento e da busca de uma época.

Ao mesmo tempo que condensam a experiência subjetiva de um periodo traumático, denunciando, pela força do desejo, a distância e a ausência, estes poemas buscam a raiz num poeta que acredita no que agora se duvida. Por trás, está um projeto que se esgarçou, mas, roto e desfigurado embora, pôde ser vestido por outra geração, vinte anos depois, revelando por entre seus fios de scosturados, segredos e hesitações da composição antes inconsútil.

\section{Notas}

1 Só na segunda edição passaram a ser onze os poemas. A pesquisadora $M$. Lúcia de Barros Camargo analisa longamente esta série em seu doutorado ("Atrás dos olhos pardos: uma leitura da poesia de Ana Cristina César", FFLCH-USP, 1990, ps. 110-111) e transcreve o manuscrito do décimoprimeiro poema, "Arte-manhas de um gasto gato", composto talvez a quatro mãos em 2/10/72, na Biblioteca da PUC do Rio. Parece-lhe provável que este seja o primeiro da série, pois nele já se encontra o mesmo tema dos outros poemas, além da data corresponder às dos poemas iniciais. Vem acompanhado de rabiscos e do comentário “Nào sei desenhar gato!". Há, nele, várias referências a Eliot e mesmo uma alusão a Drummond. Talvez Armando Freitas Filho tenha decidido nào publicá-lo na primeira edição de Inéditos e dispersos porque 
assemelha-se mais a uma brincadeira ou rascunho inicial. $\mathrm{Na}$ segunda ediçào, porém, o poema aparece como último da sequência, como um mote em desenvolvimento. A tese de Maria Lúcia de Barros Camargo detém-se longamente na análise desta sequência de poemas, de forma que a considero fonte de diálogo. 2 Ver especialmente o livro de Luiz Busatto, Montagem em Invenção de Orfeu. Rio de Janeiro: Âmbito, 1978, em que o autor compara minuciosamente passagens de Virgílio, na tradução de Odorico Mendes, e de Jorge de Lima. Para ele, seguindo o conceito de intertextualidade de Kristeva, em toda modernidade, "o texto poético é produzido no movimento complexo de uma afirmação e de uma negação simultânea de um outro texto" (p. 14).

$3 \mathrm{Na}$ verdade, este artigo é um excerto de pesquisa maior. Por uma questào de economia de espaço, foi necessário selecionar trechos da análise: resolvemos deixar de fora as leituras dos terceiro, quarto, sexto e nono poemas da sequência.

4 Esse trecho, aliás, alude a versos de Virgílio, na Geórgica. Na tradução de Antônio Feliciano de Castilho: "O céu me não dê nunca a tentação funesta/de adormecer ao ar, na lomba da floresta/sobre uma cama de erva, ao tempo em que a serpente/muda as roupas, remoça, e vaga refulgente;/onde há musgo, onde abunda erva sucosa e fria" (citados na p. 120 de Montagem em Invenção de Orfeu, de Luiz Busatto). Na recriação de Jorge de Lima, a serpente é retirada de cena, mas sua presença aparece subreptícia, pelo eco aliterativo do som sibilante e pelo tom do vocabulário: visgo, sedução, tentaçào funesta...

5 Ver o excelente ensaio de J. M. Gagnebin, "Do conceito de Mímesis no pensamento de Adorno e Benjamin", em Sete aulas sobre linguagem e memória, ps. 81106. Rio de Janeiro: Imago, 1997.

\section{Bibliografia sumária}

ANDRADE, F. de S. (1997). O engenbeiro noturno. Sào Paulo: EDUSP. 
BRITO, A.C. de (1997). (Cacaso) Não quero prosa (org. e intr. Vilma Arêas) Rio de Janeiro e Campinas: UFRJ e Unicamp.

BUSATTO, L. (1978). Montagem em Invenção de Orfeu. Rio de Janeiro: Âmbito.

CAMARGO, M. L. de B. (1990) . Atrás dos olhos pardos: uma leitura da poesia de _Ana Cristina César (Tese de doutorado defendida na FFLCH - USP)

CÉSAR, A. C. (1985). Inéditos e dispersos. São Paulo: Brasiliense.

HAMBURGER, M. (1991). La verdad de la poesia - tensiones en la poesía moderna de Baudelaire a los años sesenta. México: Fondo de Cultura Económica.

HEGEL, W.F. (1972). Estética. A arte clássica e a arte romântica (vol. IV) Lisboa: Guimaràes.

JAMESON, F. (1996). Pós-modernismo, a logica do capitalismo tardio. São Paulo: Ática.

LIMA, J. de (1958). Obra Completa. Rio de Janeiro: Aguilar, (além da poesia e dos escritos autobiográficos em prosa, embaso-me nos ensaios introdutórios de Waltensir Dutra, "Descoberta, integração e plenitude de Orfeu; Euríalo Canabrava, "Jorge de Lima e a expressão poética"; e João Gaspar Simôes, "Nota preliminar" - a Invenção de Orfeu).

LIMA, R.H.S.C. (1994). O desejo na poesia de Ana Cristina César (1952/83) Escritura de T(e)s. São Paulo: Annablume.

LOBO, L. (1993). "Dez anos de literatura feminina brasileira", "A (der)rota na metáfora da navegação" e "O clássico e o moderno em Invenção de Orfeu" em Crítica sem juizo. Rio de Janeiro: Francisco Alves.

MENDES, M. (1952). "Invençào de Orfeu", "A luta com o anjo" e "Os trabalhos do poeta" (série de artigos transcritos no apêndice de: Lima, J. Invenção de Orfeu. Rio de Janeiro: Livros de Portugal, 1a. ediçào).

MORICONI, 1. (1996). Ana Cristina César. Rio de Janeiro: Relume Dumará.

PERLOFF, M. (1991). Radical Artifice (Writing Poetry in the Age of Media). Chicago: University Press.

SANTIAGO, S. (1989). Nas malhas da letra. São Paulo: Cia. das Letras.

SIMOัES, J.G. (1952). "Nota preliminar" in: Lima, J. Invenção de Orfeu. Rio de Janeiro: Livros de Portugal. 
SIMON, I.M. (1995). "Esteticismo e participação: as vanguardas poéticas no contexto brasileiro (1954-1969)" em Pizarro, A. (org.) América Latina, literatura e cultura, vol. III. São Paulo, Campinas: Memorial da América Latina/UNICAMP. SUSSEKIND, F. (1995). Até segunda ordem não me risque nada. Rio de Janeiro: Sette Letras.

(1985). Literatura \& Vida literária (polêmicas, diários e retratos). Rio de Janeiro: Jorge Zahar.

VIEGAS, A.C. (1998). Bliss \& Blue. Segredos de Ana C. São Paulo: Annablume. 